\title{
The transposition pattern of the Ac element in tobacco cultured cells
}

\author{
Endang Semiarti ${ }^{1,2}$, Hitoshi Onouchi ${ }^{1,3}$, Satomi Torikai ${ }^{1}$, Takaaki I shikawa $^{1}$, \\ Yasunori Machida ${ }^{1}$ and Chiyoko Machida ${ }^{1 *}$ \\ ${ }^{1}$ Laboratory of Developmental Biology, Division of Biological Science, Graduate School of Science, \\ Nagoya U niversity, Chikusa-ku, Nagoya 464-8602, J apan \\ ${ }^{2}$ Permanent address: Faculty of Biology, Gadjah Mada University, Sekip Utara, \\ Yogyakarta 55281, Indonesia. \\ ${ }^{3}$ Present address: Division of Applied Bioscience, Graduate School of \\ Agriculture, Hokkaido University, Sapporo 060-8589, J apan.
}

(Received 19 J anuary 2001, accepted 24 J anuary 2001)

\begin{abstract}
We investigated physical distances and directions of transposition of the maize transposable element Ac in tobacco cultured cells. We introduced a T-DNA construct that carried a non-autonomous derivative of Ac (designated dAc-I-RS) that included sites for deavage by restriction endonucleaseMlul. Another cleavage site was also introduced into the T-DNA region outside of the dAc-I-RS transposable element. The tobacco cultured cell line BY-2 was transformed with theT-DNA and several transformed lines that had a single copy of theT-DNA at a different chromosomal location were isolated. These lines were co-cultured with Agrobacterium tumefaciens cells that carried a cDNA for the Actransposase gene under the control of various promoters. Sublines of cultured cells in which dAc-I-RS had been transposed, were isolated. The genomic DNAs of these sublines were isolated and digested with Mlul. Sizes of DNA segments generated by digestion were determined by pulse-field gel electrophoresis. Our results showed that 20 to $70 \%$ of transposition events had occurred within several hundreds kilo-base pairs $(\mathrm{kb})$ on the same chromosome. These results demonstrate that the Ac-Ds element preferentially transposed to regions near the original site in a tobacco chromosome. In addition, the present results are an example of asymmetric transposition as demonstrated by the distance of transposition on the chromosome.
\end{abstract}

\section{INTRODUCTION}

Development of recombinant DNA technology for manipulation of large segments of DNA is of importance for structural and functional analyses of plant chromosomes. The Ac element in maize is a transposable DNA element that moves from one site to another on chromosomes. Use of the Ac element has been tested for such a purpose in maize and in various heterologous plant species (Baker et al., 1986; Walbot, 1992; Bancraft et al., 1993; Chunk et al., 1993; Long et al., 1993; J ones et al., 1994; Whitham et al., 1994; J ames et al., 1995; Springer et al., 1995; Machida et al., 1997; Izawa et al., 1997; Enoki et al., 1999; Nakagawa et al., 2000a).

An understanding of the Ac element transposition pattern on a chromosome is important for its successful use in genetagging. Previous genetic investigations have

Edited by Eiichi Ohtsubo

* Corresponding author. E-mail: chiy@bio.nagoya-u.ac.jp shown that the Ac element is preferentially transposed to a region within the same chromosome (van Schaik et al., 1959; Greenblatt and Brink, 1962; Greenblatt, 1984; Dooner and Belachew, 1989; J ones et al., 1990; Dooner et al., 1991; Osbone et al., 1991; Moreno et al., 1992; Bancroft and Dean, 1993; Carrol et al., 1995; Machida et al., 1997; I to et al., 1999; Nakagawa et al., 2000a). Insertion mutation of genes near the chromosomal location of the Ac element have, in fact, been obtained and the causative genes have been cloned (Delong et al., 1993; J ones et al., 1994; Whitham et al., 1994; J ames et al., 1995; Seki et al., 1999). Preferential transposition of Drosophila $P$ elements to nearby chromosomal sites has also been reported (Tower et al., 1993). In Arabidopsis plants, we have shown that $50 \%$ of transposition events involving dAc-I-RS, a derivative of the Ac el ement constructed in our laboratory, had occurred within $1,700 \mathrm{~kb}$ on the same chromosome, with 35\% within $200 \mathrm{~kb}$. Although the Ac element has been shown to preferentially transpose to linked chromosomal locations in tobacco plants (J ones et 
al., 1990), the pattern of Actransposition at the molecular level has not yet been analyzed.

In the present study, we investigated the efficiency of reinsertion after Ac excision, and determined distances and directions of Ac transposition on the chromosomes of tobacco BY-2 cultured cells. In 20 to $70 \%$ of BY-2 cell lines in which transposition occurred, this element was transposed to various locations on the chromosome within a region of approximately several hundreds kilo-base pairs (kb) from the original site. The importance of understanding the Ac transposition pattern is discussed with regard to the manipulation of chromosomes and gene tagging in tobacco plants.

\section{MATERIALS AND METHODS}

Plant cells and bacterial strains. Suspension cultures of the cell line BY-2 of tobacco (Nicotiana tabacum L. Cv. Bright Yellow 2) have been described elsewhere (Kato et al., 1972). BY-2 cells were used for isolation of transgenic lines T/dAc\#8, \#12,\#13 and \#19, which carried a single copy of (I-RS/dAC-I-RS)T-DNA (Fig. 1A). Agrobacterium tumefaciens EHA101 (Hood et al., 1986) and LBA4404/pAL 4404 (Hoekema et al., 1983) were used as the hosts for BY-2 transformation.

Enzymes, chemicals and plasmids. Restriction and modifying enzymes were purchased from Takara Shuzo Co. Ltd. (Kyoto, J apan) or Toyobo Co. Ltd. (Osaka, J apan). Hygromycin B and kanamycin sulfate were obtained from Wako Pure Chemical Industries Ltd. (Osaka, J apan). Cellulase Onozuka RS and Pectolyase Y-23 for the preparation of protoplasts were purchased from Y akult Co. Ltd. (Tokyo, J apan) and Seisin Pharmaceutical Co. Ltd. (Tokyo, J apan), respectively.

Plasmids and their relevant characteristics are listed in

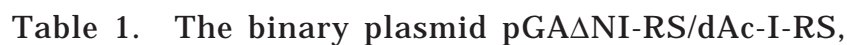

which contained (I-RS/dAc-I-RS)T-DNA (Fig. 1A) (The GenBank accession number of dAc-I-RS is AB055064), and the binary plasmid pGAH $\Delta$ N 35SAcTPase, which contained the CDNA that correspond to the gene for AC transposase were described previously (Kunze et al., 1987; Machida et al., 1997). The binary plasmids pGAH$\Delta \mathrm{N}$ parAcTPase and pGAH $\Delta \mathrm{N} 2$ 'AcTPase contained the Ac transposase gene under the control of parA promoter (Niwa et al., 1994) and 2' promoter (Velten et al., 1984), respectively.

Induction of dAC-I-RS transposition by introducing Ac transposase and selection of plant cells with a transposed dAc-I-RS. A modified co-culture method was used for transient introduction of the Ac transposase gene into the transformed BY-2 cells. Cells of A. tumefaciens EHA101 harboring pGAH $\Delta$ N35SAcTPase, pGAH $\Delta$ NPparAcTPase or pGAH $\Delta$ N p2'AcTPase were cultured until the absorbance at $600 \mathrm{~nm}$ was 1.5, and the culture was concentrated four-fold. A $100 \mu \mathrm{l}$ aliquot of this culture was mixed with $4 \mathrm{ml}$ of a suspension culture of transformed BY-2 cell lines, T/dAc \#8, \#12, \#13, and \#19, which carried a single copy of (I-RS/dAc-I-RS)T-DNA. The mixture was incubated in Linsmaier and Skoog (LS) medium (Linsmaier and Skoog, 1965) containing 0.2 mg/l 2,4-D at $22^{\circ} \mathrm{C}$ in the dark for $24-144 \mathrm{hr}$. Cells were se lected for resistance to kanamycin in LS medium, which was supplemented with $0.2 \mathrm{mg} / \mathrm{l}$ 2,4-D and 100 or $200 \mathrm{mg} /$ I kanamycin. Cells that showed resistance to kanamycin were transferred to a plate containing LS medium supplemented with $0.2 \mathrm{mg} / \mathrm{l}$ 2,4-D, $100 \mathrm{mg} / \mathrm{l}$ kanamycin and 50 $\mathrm{mg} / \mathrm{l}$ hygromycin to check for reinsertion of dAc-I-RS.

Extraction of DNA and PCR analysis. DNA was extracted from the cells by the cetyltrimetylammonium bromide method (Murray and Thompson, 1980) and used as a template for amplification by the polymerase chain reaction $(P C R)$. PCR was carried out in a DNA Thermal

Table 1. Plasmids used in this study

\begin{tabular}{|c|c|c|}
\hline Plasmid & Relevant characteristics & Reference \\
\hline $\mathrm{pGA} \Delta \mathrm{NI}-\mathrm{RS} / \mathrm{dAc}-\mathrm{I}-\mathrm{RS}$ & Derivative of $\mathrm{pGAH} \Delta \mathrm{N}$ containing the (I-RS/dAc-I-RS)T-DNA & $\begin{array}{l}\text { Machida et al. (1997) (Fig. 1) } \\
\text { (GenBank ac. no. AB055064) }\end{array}$ \\
\hline pGAH $\Delta$ NPparAcTPase & $\begin{array}{l}\text { Derivative of pGAH } \Delta \mathrm{N} \text { containing the cDNA for Ac transposase gene } \\
\text { under the control of par promoter }\end{array}$ & Machida et al. (1997) \\
\hline pGAH $\Delta \mathrm{Np2}$ 'AcTPase & $\begin{array}{l}\text { Derivative of pGAH } \Delta \mathrm{N} \text { containing the } \mathrm{CDNA} \text { for Ac transposase gene } \\
\text { under the control of } 2 \text { ' promoter }\end{array}$ & This study \\
\hline pGAH $\Delta$ N35SAcTPase & $\begin{array}{l}\text { Derivative of pGAH } \triangle \mathrm{N} \text { containing the CDNA for Ac transposase gene } \\
\text { under the control of P35S }\end{array}$ & Machida et al. (1997) \\
\hline pGA492 & $\begin{array}{l}\text { Binary vector plasmid containing the neomycin phosphotransferase II } \\
\text { gene and a multiple cloning site }\end{array}$ & An (1987) \\
\hline pGA492 $\triangle$ NBP & $\begin{array}{l}\text { Derivative of pGA492 containing a deletion of the region of the } \\
\text { neomycin phosphotransferase II gene }\end{array}$ & This study \\
\hline $\mathrm{pGAH} \Delta \mathrm{N}$ & $\begin{array}{l}\text { Derivative of pGAH containing a deletion of the region of the neomycin } \\
\text { phosphotransferase II gene }\end{array}$ & Onouchi et al. (1995) \\
\hline
\end{tabular}


Cycler (Perkin-E Imer Cetus, USA) using $0.1 \mu \mathrm{g}$ of genomic DNA in a total volume of $50 \mu \mathrm{l}$. The amplification included $30 \mathrm{cycles}$ of 30 second denaturation at $94^{\circ} \mathrm{C}, 1$ min annealing at $60^{\circ} \mathrm{C}$ and 3 min elongation at $72^{\circ} \mathrm{C}$. The reaction mixture was analyzed on a $4 \%$ polyacrylamide gel. The sequences of the primers (Fig. 1A) were 5'-TACTTACGTCACGTCTTGCG-3' (1'pro), 5'-ACCTGCGTGCAATCCATCTT-3' (NPTIIUP), 5'-TTACCTCGGGTTCGAAATCG-3' (AcUP), 5'-GGATGTATGGCAGCATTTCA-3' (ACL1), and 5'-GTCCACAGTGATATGATCTC-3' (RS1).

Preparation of high molecular weight DNA and digestion with Mlul. High molecular weight DNA from tobacco BY -2 cultured cells was isolated from protoplasts prepared by the method of Nagata et al. (1981). Protoplasts were suspended in $0.6 \mathrm{M}$ mannitol, at a final concentration of approximately $2 \times 10^{8}$ protoplasts $/ \mathrm{ml}$. High molecular weight DNA was prepared from protoplasts following the methods of Guzmán and Ecker (1988) and Machida et al. (1997). For digestion with Mlul, agarose plugs were placed in a solution of $50 \mathrm{mM}$ EDTA (pH 8.0) and incubated for $2 \mathrm{hr}$ at $25^{\circ} \mathrm{C}$ to inactivate proteinase $\mathrm{K}$. The plugs were then transferred to a solution of $50 \mathrm{mM}$ EDTA (pH 8.0) and $1 \mathrm{mM}$ phenylmethylsulfonyl fluoride (PMSF) and incubated overnight at $4{ }^{\circ} \mathrm{C}$. The plugs were next transferred to a solution containing $10 \mathrm{mM}$ Tris- $\mathrm{HCl}$ and $0.1 \mathrm{mM}$ EDTA ( $\mathrm{pH}$ 8.0) and incubated for $2 \mathrm{hr}$ at $25^{\circ} \mathrm{C}$. After transfer to fresh solution, the plugs were stored at $4^{\circ} \mathrm{C}$ until use. The plugs were transferred to Mlul reaction solution and incubated for $2 \mathrm{hr}$ at $37^{\circ} \mathrm{C}$, twice, and then transferred to fresh solution and incubated for $16 \mathrm{hr}$ at $37^{\circ} \mathrm{C}$ after the addition of Mlul .

Conditions for pulse-field gel electrophoresis. Pulse-field gel electrophoresis (PFGE) was performed as previously described (Machida et al., 1997) in an LKB pulsaphore (PharmaciaLKB, Uppsala, Sweden).

\section{RESULTS AND DISCUSSION}

Experimental design for measurement of transposition distances by Mlul. Fig. 1A shows theT-DNA construct we made for the investigation of distances and direction of transposition. The T-DNA construct contained the Mlul recognition site inside and outside of the modified Ac transposable element [we designated this element and the T-DNA, dAc-I-RS and I-RS(dAc-I-RS)TDNA, respectively (Machida et al: 1997)]. When transposition of dAc-I-RS occurs within the same chromosome, digestion of genomic DNA by Mlul should give rise to a segment of chromosomal DNA flanked by part of the TDNA at the original integration site and part of the transposed dAc-I-RS sequence (see Fig. 1B). Using two DNA fragments as probes (probes 1 and 2) for Southern hybridization, we were able to distinguish the relative direction
A

(I-RS/dAc-I-RS)T-DNA
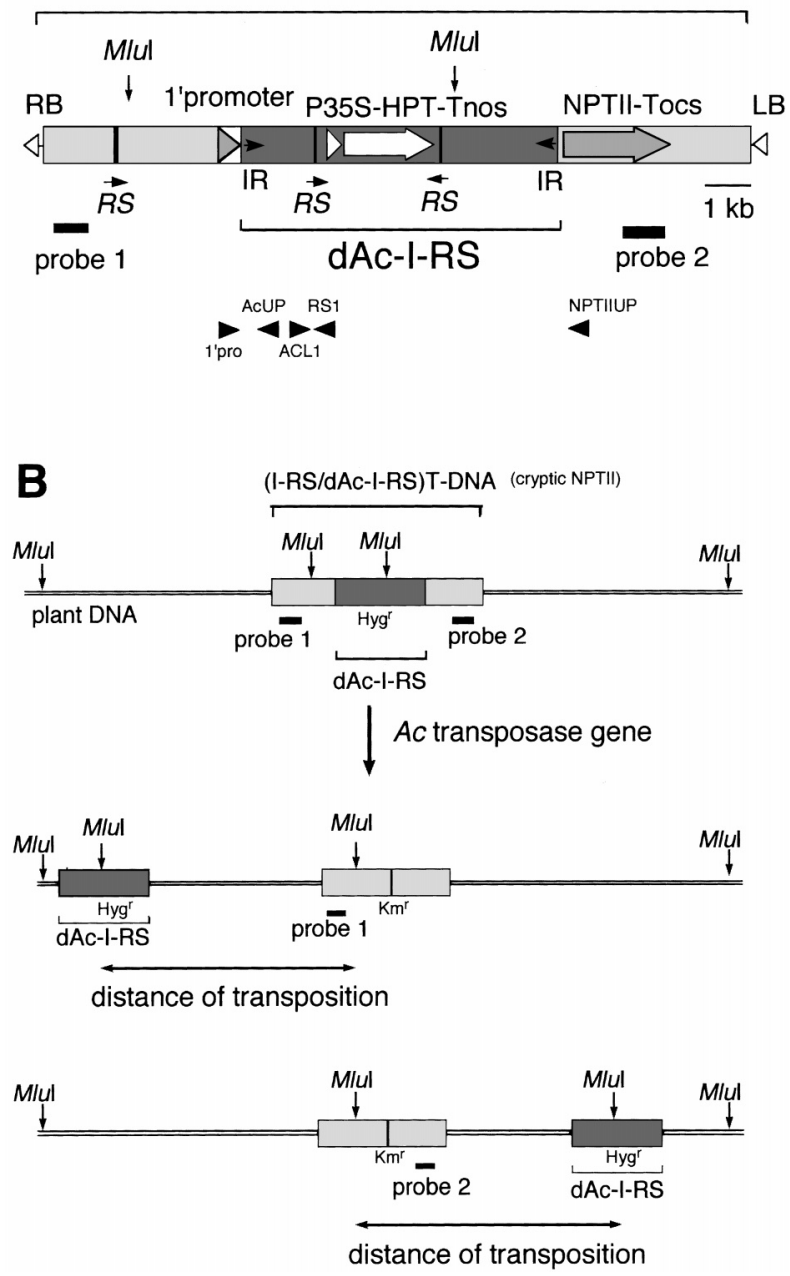

Fig. 1. (A) Schematic diagram of the (I-RS/dAC-I-RS)T-DNA construct in plasmid pGA $\Delta \mathrm{NI}-\mathrm{RS} / \mathrm{dAc}-\mathrm{I}-\mathrm{RS}$. dAc-I-RS indicates the non-autonomous derivative of the Ac element that contained the cleavage site for restriction endonuclease Mlul and RS sequences (see text). RB and LB indicate right and left border sequences on the T-DNA, respectively. 1' promoter, the 1' promoter of the octopine Ti plasmid TR-DNA; P35S, the promoter of the gene for 35S RNA from cauliflower mosaic virus; HPT, the coding sequence of the gene for hygromycin phosphotransferase; NPTII, the coding sequence of the gene for neomycin phosphotransferase II; Tnos, the terminator of the gene for nopaline synthase; Tocs, the transcriptional terminator of the gene for octopine synthase; IR, the terminal inverted repeat sequences of $A c$; RS, the recombination site that is recognized by the R protein from Zygosaccharomyces rouxii. Thick lines indicate the probes (probes 1 and 2) used for Southern blotting analysis. Arrowheads indicate the primers used for PCR (Materials and Methods). (B) The strategy for measurement of the distance of transposition. Mlul indicates sites of cleavage by the restriction endonuclease Mlul. Putative cleavage sites for Mlul are also indicated on plant DNAs. A dark gray box indicates dAc-I-RS. Light gray boxes indicate regions of T-DNA other than dAc-I-RS in (I-RS/dAc-IRS)T-DNA. 
of each transposition. We also introduced RS sequences, namely, recognition sites for recombinase (R protein) from Zygosaccaromyces rouxii (Araki et al.,1985, Matsuzaki et al., 1988, Araki et al., 1992) into the T-DNA construct: two RSs in inverted orientation were placed inside and outside dAc-I-RS, respectively, as described previously (Machida et al., 2000). In addition to such specific DNA sequences, we inserted the gene for hygromycin phosphotransferase (HPT) under the control of a $35 \mathrm{~S}$ promoter into the dAc-I-RS element for selection of transgenic cell lines and detection of dAC-I-RS insertion (Fig. 1B). For monitoring the excision of dAc-I-RS, this element was inserted between the 1' promoter (Velten et al., 1984) and the coding sequence of the element for neomycin (kanamycin) phosphotransferasell (cryptic NPTII) (Baker et al., 1987). Thus, excision of dAc-I-RS should create an active NPTII gene in transgenic Arabidopsis plants that contain (I-RS/dAC-I-RS)T-DNA.

Isolation of transgenic tobacco cultured BY-2 cell lines that contained the (I-RS/dAc-I-RS)T-DNA and induction of transposition. We isolated transformed tobacco cultured BY-2 cells that contained (I-RS/dAc-IRS)T-DNA, and we selected four transgenic lines that had a single copy of the T-DNA. We designated these lines T/ $\mathrm{dAc} \# 8, \# 12, \# 13$ and \#19.

In order to express the Ac transposase, we linked three types of promoter sequences to the CDNA encoding the transposase: the promoter of the tobacco par gene, whose activity was shown to be higher in BY-2 cells than that of the 355 promoter of cauliflower mosaic virus (P35S) (Niwa et al., 1994), P35S (Guilley et al., 1982), and the promoter of the 2' gene from T-DNA (Velten et al., 1984). We cocultured the transformed BY-2 lines with cells of $A$. tumefaciens EHA101 harboring pGAH $\triangle$ NPparAcTPase that carried the gene for Ac transposase under the control of the par promoter (Materials and M ethods). Numbers of kanamycin resistance cells were counted at various times after an onset of co-culturing. As shown in Table 2 , kanamycin resistance cells appeared in both $\mathrm{T} / \mathrm{dAc \# 12}$ and \#19 lines 48 hours after co-culturing and numbers of kanamycin resistance calli increased as co-culturing continued (Table 2, lanes 1 and 3). When cells were cocultured with Agrobacterium that harbored pGA492$\triangle N B P$, which did not contain the Ac transposase gene, no resistant callus was observed (Table 2, lanes 2 and 4). These results show that our construct encoding Ac transposase can mediate excision of dAc-I-RS in tobacco cultured cells. We also examined the frequency of excision mediated by the Ac transposase gene under the control of promoters other than the par promoter. As shown in Table 3, P35S was shown the most effective for introducing excision. We decided to use the construct pGAH $\triangle$ N35SAcTPase for induction of transposition in further experiments.

To examine DNA structures after induction of dAc-I-RS excision in each transformed cell line, we established sublines of cells that showed resistance for kanamycin after co-culturing with the Agrobacterium cells containing the Ac transposase gene. Total chromosomal DNAs were

Table 2. Numbers of $\mathrm{Km}^{\mathrm{r}}$ calli after onset of coculture with Agrobacterium cells that carried the Ac transposase gene.

\begin{tabular}{|c|c|c|c|c|c|}
\hline \multirow{2}{*}{$\begin{array}{l}\text { Cryptic NPTII gene } \\
\text { in transformed line }\end{array}$} & \multirow[b]{2}{*}{ Binary vector } & \multicolumn{4}{|c|}{$\begin{array}{l}\text { Number of } \mathrm{Km}^{\mathrm{r}} \text { calli of BY-2 transformed cells with the cryptic NPTII after } \\
\text { coculture with Agrobacterium cells that carried the Ac transposase gene for }\end{array}$} \\
\hline & & $24 \mathrm{hr}$ & $48 \mathrm{hr}$ & $72 \mathrm{hr}$ & $96 \mathrm{hr}$ \\
\hline $\mathrm{T} / \mathrm{dAc \# 12}$ & pGAH $\Delta$ NPparAcTPase & 0 & 9 & 26 & 126 \\
\hline $\mathrm{T} / \mathrm{dAc \# 12}$ & pGA492 2 NBP & 0 & 0 & 0 & 0 \\
\hline $\mathrm{T} / \mathrm{dAc \# 19}$ & pGAH $\Delta$ NPparAcTPase & 0 & 6 & 17 & 59 \\
\hline $\mathrm{T} / \mathrm{dAc \# 19}$ & pGA492 $\triangle$ NBP & 0 & 0 & 0 & 0 \\
\hline
\end{tabular}

$7 \times 10^{5}$ cells of BY-2 were examined on each experiment.

Table 3. Numbers of $\mathrm{Km}^{r}$ calli after onset of coculture with Agrobacterium cells that carried the Ac transposase gene under the control of various promoters.

\begin{tabular}{|c|c|c|c|}
\hline $\begin{array}{l}\text { Cryptic NPTII gene } \\
\text { in transformed line }\end{array}$ & Binary vector & $\begin{array}{l}\text { Promoter for } \\
\text { transposase gene }\end{array}$ & Number of $\mathrm{Km}^{\mathrm{r}}$ calli \\
\hline $\mathrm{T} / \mathrm{dAc \# 12}$ & pGAH $\Delta$ NPparAcTPase & par promoter & 30 \\
\hline $\mathrm{T} / \mathrm{dAc \# 12}$ & pGAH $\Delta \mathrm{Np2}$ 'AcTPase & 2' promoter & 1 \\
\hline $\mathrm{T} / \mathrm{dAc \# 12}$ & pGAH $\Delta \mathrm{N} 35 \mathrm{SAcT}$ Pase & P35S & 43 \\
\hline $\mathrm{T} / \mathrm{dAc \# 12}$ & pGA492 $N$ NP & no & 0 \\
\hline $\mathrm{T} / \mathrm{dAc \# 19}$ & pGAH $\triangle$ NPparAcTPase & par promoter & 22 \\
\hline $\mathrm{T} / \mathrm{dAc \# 19}$ & pGAH $\Delta \mathrm{Np2}$ 'AcTPase & 2' promoter & 0 \\
\hline $\mathrm{T} / \mathrm{dAc \# 19}$ & pGAH $\triangle N$ 35SAcTPase & P35S & 23 \\
\hline $\mathrm{T} / \mathrm{dAc \# 19}$ & pGA492 $\triangle N B P$ & no & 0 \\
\hline
\end{tabular}

$7 \times 10^{5}$ cells of BY-2 were examined on each experiment. 
purified from the kanamycin resistant cells and subjected to analysis by PCR using appropriate combinations of oligonucl eotide primers (Fig. 1). We used primers 1'pro and NPTIIUP for detection of empty sites after excision of the dAc-I-RS element. As shown in Fig. 2, when the cells of the $T / \mathrm{dAC \#}-\mathrm{K} 2$ and $\mathrm{K} 3$ sublines that showed resistance to kanamycin were examined, approximately 261-bp fragments were amplified (lane 1). Polynucleotides of this length are expected if excision of the dAc-I-RS occurs. However, when the primers I'pro and AcUP, by which we could examine the preexcision sequence, were used, no fragment was amplified in these lines (lane 2). When the genomic DNA of the cells in the T/dAc\#8 line (before induction of transposition) was examined using l'promoter AcUP primers, a 277-bp fragment was amplified (Fig. 2, lane 2).

When another combination of primers (ACL1 and RS1, by which we could examine the presence of dAc-I-RS) was used, DNA fragments with expected sizes were amplified before and after induction of transposition (Fig. 2, lane 3). These data suggest that dAc-I-RS was reinserted into chromosomal DNA in each of the cell lines.

The sublines of cells that showed resistance to kanamycin were examined for resistance to hygromycin. Wealso
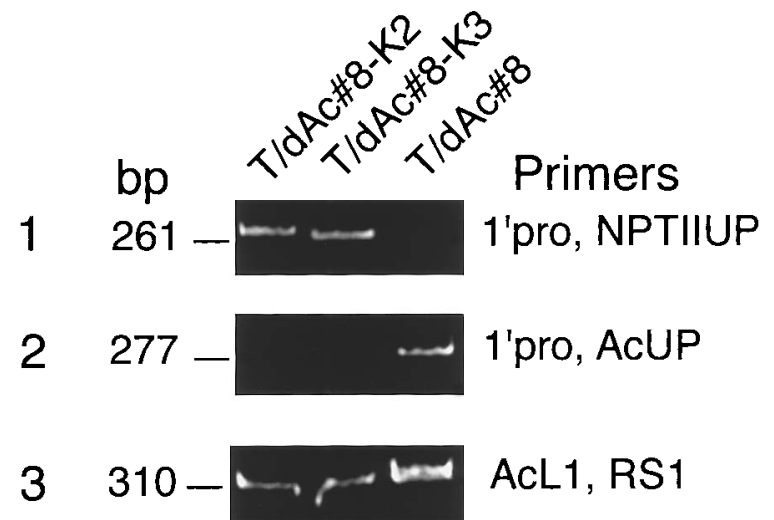

Fig. 2. Analysis of PCR products after induction of dAC-I-RS excision by Ac transposase. Template DNAs were extracted from the T/dAc\#8-K2 subline (column 1), the T/dAc\#8-K 3 subline (column 2), and the T/dAc\#8 line (column 3). PCR was performed as described in Materials and Methods using primers (Fig. 1A) that depicted on the right. Amplified DNA products were fractionated on a $4 \%$ polyacrylamide gel. Numbers on the left indicate length (base pairs) of PCR products. carried out Southern blotting and PCR analysis using genomic DNAs from the cells to examine the reinsertion of dAc-I-RS. Between 33 and $88 \%$ of the sublines that exhibited resistance to kanamycin were resistant to hygromycin and carried transposed dAc-I-RS elements (Table 4), but they did not have a stable Ac transposase gene.

Measurement of physical distances of transposition. High-molecular-weight chromosomal DNA from the T/ dAc\#8 line before transposition was purified, digested with Mlul, and DNA segments were fractionated by pulse-field gel el ectrophoresis (PFGE) and subjected to Southern blot analysis using probes 1 and 2 (see Fig. 1). When probe 2 was used, the 700-kb fragment was detected as shown in Fig. 3 (lane 1). With probe 1, the 400-kb fragment was similarly detected (data not shown). Thus, in the genomic DNA of the T/dAc\#8 cell line, the Mlul sites nearest to the (I-RS/dAC-I-RS)T-DNA insertion site were mapped $400 \mathrm{~kb}$ and $700 \mathrm{~kb}$ toward RB and LB, respectively (see Fig. 4). When dAc-I-RS transposes within these Mlul sites in the $T / d A c \# 8$ line, the distances and directions of transposition can be measured by Mlul .

Subsequently, we analyzed Mlul digests of chromosomal DNAs from eight sublines of cells, which were derived from the T/dAc\#8 line and had transposed dAc-I-RS elements. In five out of eight sublines, detected DNA bands were shorter in size than the detection limits described above. Fig. 3 shows typical results of such an analysis: in four sublines, DNA fragments of $5 \mathrm{~kb}, 550 \mathrm{~kb}$, and $200 \mathrm{~kb}$ were detected with probe 2 (Fig. 3, lanes 2, 3, $5,7)$, while two sublines produced the $700-\mathrm{kb}$ fragments (Fig. 3, lanes 4 and 6). With probe 1, $400 \mathrm{~kb}$ fragments were detected in digests of DNA from all sublines (data not shown). These results show that the dAc-I-RS elements in cell line T/dAc\#8 were transposed by $5 \mathrm{~kb}, 550$ $\mathrm{kb}$, and $200 \mathrm{~kb}$ toward the left border (LB) of the T-DNA, respectively, and no element transposed leftward to the right border (RB) within $400 \mathrm{~kb}$ (Fig. 4).

In the T/dAc\#12 cell line, Mlul sites nearest to the (IRS/dAc-I-RS)T-DNA were mapped $700 \mathrm{~kb}$ and $600 \mathrm{~kb}$ toward RB and LB, respectively (Fig. 4). We also analyzed transposition events in this cell line using Mlul. When we measured the sizes of Mlul digests of genomic DNAs from ten sublines that were derived from the T/dAc\#12 line and had transposed dAc-I-RS elements, only two sub-

Table 4. Reinsertion frequency of dAc-I-RS element

\begin{tabular}{lcc}
\hline \hline Transformed lines & Number of $\mathrm{Km}^{\mathrm{r}}$ calli & Number of $\mathrm{Km}^{\mathrm{r}}$ and $\mathrm{Hyg}^{\mathrm{r}}$ calli $(\%)$ \\
\hline T/dAc\#8 & 8 & $7(88)$ \\
T/dAc\#12 & 17 & $13(76)$ \\
T/dAc\#13 & 18 & $6(33)$ \\
T/dAc\#19 & 7 & $4(57)$ \\
\hline
\end{tabular}

Values in parentheses represent the percentages of $\mathrm{Km}^{r}$ and $\mathrm{Hyg}^{r}$ calli per $\mathrm{Km}^{\mathrm{r}}$ calli. 


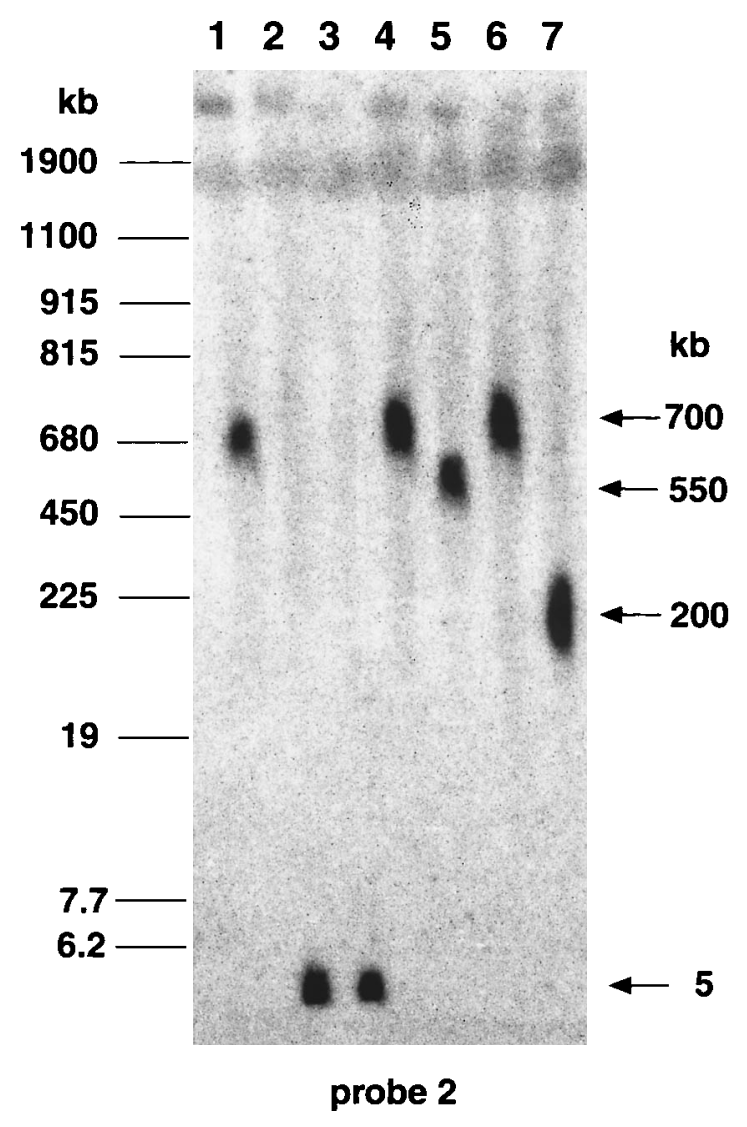

lines produced DNA segments that were shorter in size than the detection limits described above. Fragments of $200 \mathrm{~kb}$ and $5 \mathrm{~kb}$ were detected by probe 1 and probe 2 , respectively (data not shown). These results showed that the $d A c-I-R S$ elements in the T/dAc\#12 line were transposed by $200 \mathrm{~kb}$ and $5 \mathrm{~kb}$ toward the RB and LB of the T-DNA, respectively ( $\mathrm{Fig} .4$ ).

We examined the orientation of the transposed dAc-IRS elements at the insertion sites using probes that contained sequences specific for the left or the right side of the Mlul site in dAc-I-RS. The results of these experiments showed that the dAc-I-RS el ement could beinserted in both possible orientations (data not shown).

Using the dAc-I-RS element that contained the MIul site, we examined the physical distances and directions of

Fig. 3. Southern blot analysis for measurement of dAc-I-RS transposition distance by pulse-field gel electrophoresis. High molecular weight genomic DNA was prepared from cultured cells of sublines that had a transposed dAc-I-RS that originated from cell line $\mathrm{T} / \mathrm{dAc \# 8}$, as described in Materials and Methods. I solated DNA was digested with Mlul, and then fractionated by PFGE in a $1 \%$ agarose gel for $18 \mathrm{hr}$ at 170 volts with a switch interval of $80 \mathrm{sec}$, and then for $3 \mathrm{hr}$ at 170 volts with a switch interval of $110 \mathrm{sec}$. After transfer of the DNA to a nylon membrane filter, the filter was probed with probe 2. Standards are shown with size in kilo-base pairs $(\mathrm{kb})$. Lanes 1 , the T/dAc\#8 line (before transposition); Ianes 2, 3, 4, 5, 6, and 7, T/dAc\#8-K2, $\mathrm{K} 3, \mathrm{~K} 4, \mathrm{~K} 6, \mathrm{~K} 7$, and $\mathrm{K} 8$ lines.

\section{T/dAc\#8 line}

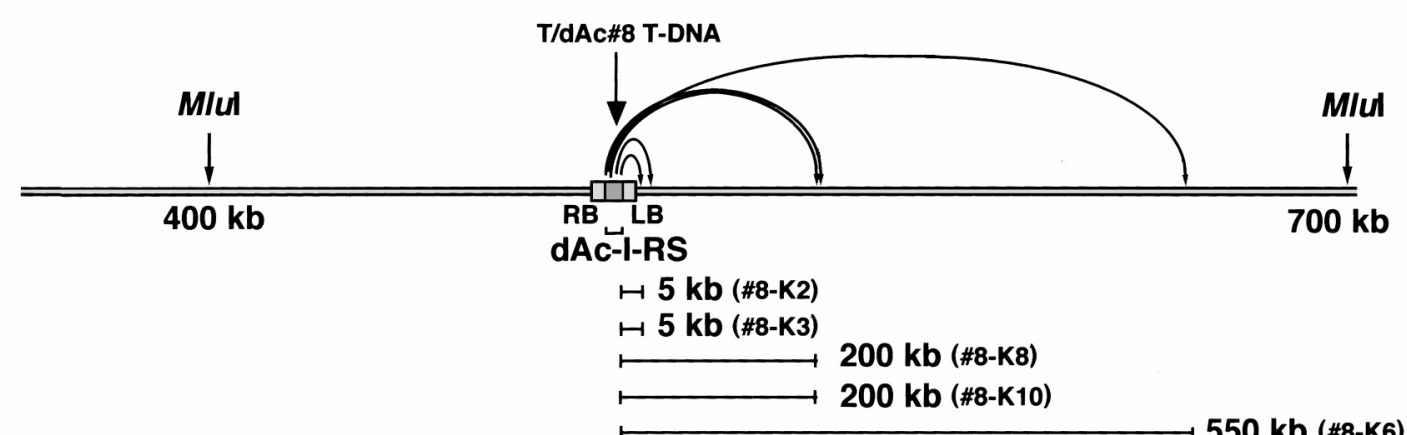

T/dAc\#12 line

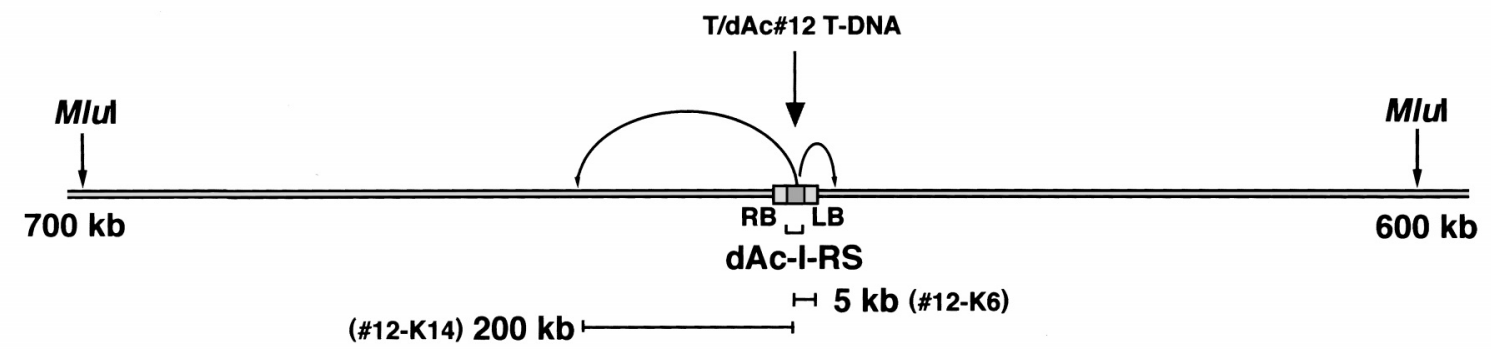

Fig. 4. Summary of the distances and directions of transposition in the T/dAc\#8 and \#12 lines. Cleavage sites for Mlul in the tobacco genome are indicated by arrows. 
Ac element transposition in two transformed BY-2 cell lines that had dAc-I-RS el ements in different chromosomal locations. Seventy percent of the transposed dAc-I-RS elements were mapped within $700 \mathrm{~kb}$ on the chromosome in the T/dAc\#8 cell line. In the T/dAc\#12 cell line, $20 \%$ of the transposed dAc-I-RS elements were mapped within $200 \mathrm{~kb}$ on both sides of the original site of these elements. Our results showed that the Ac element can be efficiently transposed to sites within a few hundreds $\mathrm{kb}$ in tobacco cells. Although transposition frequency in tobacco is higher than in Arabidopsis plants (Baker et al., 1986), the pattern of transposition in tobacco cultured cells is similar to that in Arabidopsis (Machida et al., 1997), indicating that the pattern of transposition to linked chromosomal sites is characteristic of the Ac el ement, which is independent of the frequency of transposition. This result also suggests that the Ac element is useful for disrupting genes that are present in such adjacent regions, even in the absence of strong selective pressure. Interestingly, transposition events observed in the T/ $\mathrm{dAc \# 8}$ line were also detected in only one direction within $700 \mathrm{~kb}$ : transposition was not detected in the opposite direction within $400 \mathrm{~kb}$. This is consistent with previously reported genetic analysis of asymmetric transposition (Greenblatt, 1984). However, we have to analyze more transposed lines to make such an asymmetric transposition on a chromosome more evident.

\section{Use of the transposed dAC-I-RS in combination with the R-RS site specific recombination system.} Development of recombinant DNA technology for manipulation of large segments of DNA is of importance for the structural and functional analysis of eukaryotic chromosomes. For development of this technology, the use of site-specific recombination systems, such as the cre-loxP system, the R-RS system and FLP-FRT systems, has been proposed (Onouchi et al., 1991; van Haaren and Ow, 1993; Machida et al., 1993; Medberry et al., 1995; Osbone et al., 1995; Onouchi et al., 1995). Chromosomal deletions and inversions have been induced in Arabidopsis, tobacco and rice plants by exploitation of these systems (Medberry et al., 1995; Osbone et al., 1995; Machida et al., 2000; Nakagawa et al., 2000b). However, the feasibility of exploiting this system has not been established, in particular for the induction of chromosomal deletions, because systematic analysis remains to be performed. One of the aims of our present study was to solve this problem. As shown in Fig. 1, the (I-RS/dAc-I-RS)T-DNA that we constructed contained two RS sequences, namely, recognition sites for a recombinase ( $R$ protein) from Z. rouxii (Machida et al., 1997). The tobacco cells that we generated in the present study will, therefore, be useful for a systematic examination of chromosomal deletions mediated by the RRS system since the physical distance between two RS sequences on the chromosome have been precisely deter- mined.

We are grateful to Dr. B. Baker and Dr. J . Schell (Max-Planck Institüt für Züchtungsforschung, Cologne, Germany) for their gift of the plasmid pKU3 containing $A c$, and to Dr. R. Kunze and Dr. P. Starlinger (Universität zu Köln, Cologne, Germany) for their gift of the plasmid that contained the CDNA for the AC transposase. We also thank Professor F. Osawa (Aichi Institute of Technology and the Research Development Corporation of J apan) for his encouragement. E. S. was supported by a scholarship from the Ministry of Education, Science, and Culture and Sports of J apan. This work was supported in part by grants from the Research for the Future Program of the J apan Society for the Promotion of Science (J SPS-RFTF 97L 00601 and J SPSRFTF 00L 01603) and by Grants-in-Aid for Scientific Research on Priority Areas (no. 10182101) and for General Scientific Research (no. 12640598) from the Ministry of Education, Science, and Culture and Sports of J apan, and by a grant for Pioneering Research Projects in Biotechnology from the Ministry of Agriculture, Forestry, and Fisheries of J apan.

\section{REFERENCES}

An, G. (1987) In Wu and Grossman (eds.), Binary Ti vectors for plant transformation and promoter analysis. in Methods in Enzymology. Recombinant DNA. Academic Press, Vol. 153, 292-305.

Araki, H., J earnpipatkul, A., Tatsumi, H., Sakurai, T., Ushio, K., Muta, T., and Oshima, Y. (1985) Molecular and functional organization of yeast plasmid pSR1. J . Mol. Biol. 182, 191203.

Araki, H., Nakanishi, N., Evans, B. R., Matsuzaki, H., J ayaram, M., and Oshima, Y. (1992) Site-specific recombinase, R, encoded by yeast plasmid pSR1. J. Mol. Biol. 225, 25-37.

Baker, B., Coupland, G., Fedoroff, N., Starlinger, P., and Schell, J . (1987) Phenotypic assay for excision of the maize controlling element Ac in tobacco. EMBO J . 6, 1547-1554.

Baker, B., Schell, J ., Lörz, H., and F edoroff, N. (1986) Transposition of the maize controlling el ement "Activator" in tobacco. Proc. Natl. Acad. Sci. USA 83, 4844-4848.

Bancroft, I. and Dean, C. (1993) Transposition pattern of the maize element Ds in Arabidopsis thaliana. Genetics 134, 12211229.

Bancroft, I., J ones, J. D. G., and Dean, C. (1993) Heterologous transposon tagging of the DRL 1 locus in Arabidopsis. Plant Cell 5, 631-638.

Carroll, B. J ., Klimyuk V. I., Thomas C. M., Bishop, G. J ., Harrison, K., Scofield S. R., and J ones, J . D. G. (1995) Germinal transpositions of the maize element Dissociation from T-DNA loci in tomato. Genetics 139, 407-420.

Chuck, G., Robbins, T., Nijjar, C., Ralston, E., CourtneyGutterson, N., and Dooner, H. K. (1993) Tagging and cloning of a petunia flower color gene with the maize transposable element Activator. Plant Cell 5, 371-378.

Delong, A., Calderon-Urrea, A., and Dellaporta, S. L. (1993) Sex determination gene TASSE LSEED2 of maize encodes a shortchain alcohol dehydrogenase required for stage-specific floral organ abortion. Cell 74, 757-768.

Dooner, H. K. and Belachew, A. (1989) Transposition pattern of the maize element Ac from the bz-m2 (Ac) allele. Genetics 122, 447-457.

Dooner, H. K., Keller, J ., Haper, E., and Ralston, E. (1991) Variable patterns of transposition of the maize element Activator in tobacco. Plant Cell 3, 473-482.

Enoki, H., Izawa ,T., Kawahara, M., Komatsu, M., Koh, S., 
Kyozuka, J ., and Shimamoto, K. (1999) Ac as a tool for the functional genomics of rice. Plant J 19,605-613

Greenblatt, I. M. (1984) A chromosome replication pattern deduced from pericarp phenotypes resulting from movements of the transposable element Modulator in maize. Genetics 108, 471-485.

Greenblatt, I. M., and Brink, R. A. (1962) Twin mutations in medium variegated pericarp maize. Genetics 47, 489-501.

Guilley, H., Dudley, R. K., J onard, G., Balazs, E., and Richards, K. E. (1982) Transcription of Cauliflower mosaic virus DNA: detection of promoter sequences, and characterization of transcripts. Cell 30, 763-773.

Guzmán, P. and Ecker, J . R. (1988) Development of large DNA methods for plants: molecular cloning of large segments of Arabidopsis and carrot DNA into yeast. Nucleic Acids Res. 16, 11091-11105.

Hoekema, A., Hirsch, P. R., Hooykaas, P. J . J ., and Schilperoot, R. A. (1983) A binary plant vector strategy based on separation of vir- and T-region of the Agrobacterium tumefaciens Ti-plasmid. Nature 303, 179-180.

Hood, E. E., Helmer, G. L., Fraley, R. T., and Chilton, M. D. (1986) The hypervirulence of Agrobacterium tumefaciens A281 is encoded in a region of pTiBo542 outside of T-DNA. J . Bacteriol. 168, 1291-1301.

Ito, T., Seki, M., Hayashida, N., Shibata, D. and Shinozaki, K. (1999) Regional insertional mutagenesis of genes on Arabidopsis thaliana chromosome $\mathrm{V}$ using the Ac/Ds transposon in combination with a cDNA scanning method. Plant J . 17, 433-444.

Izawa, T., Ohnishi, T., Nakano, T., Ishida, N., Enoki, H., Hashimoto, H., Itoh, K., Terada, R., Wu, C., Miyazaki, C., Endo, T., Iida., S., and Shimamoto, K. (1997) Transposon tagging in rice. Plant Mol. Biol. 35 219-229.

J ames J r, D. W., Lim, E., Keller, J ., Plooy, I., Ralston, E., and Dooner, H. K. (1995) Directed tagging of the Arabidopsis FATTY ACID ELONGATION 1 (FAE 1) gene with the maize transposon activator. Plant Cell 7, 309-319.

J ones, J. D. G., Carland, F., Lim, E., Ralston, E., and Dooner, H.K. (1990) Preferential transposition of the maize element Activator to linked chromosomal locations in tobacco. Plant Cell 2, 701-707.

J ones, D. A., Thomas, C. M., Hammond-Kosack, K. E., BalintKurti, P. J ., and J ones, J . D. G. (1994) I solation of the tomato Cf-9 gene for resistance to Cladosporium fulvum by transposon tagging. Science 266, 789-793.

Kato, K., Matsumoto T., Koiwai, A., Mizusaki, S., Nishida, K., Noguchi M. and Tamaki E. (1972) Liquid suspension culture of tobacco cells. In G. Terui (ed.) Fermentation technology today. Society of Fermentation Technology, Osaka, J apan, 689-695.

Kunze, R., Stochaj, U., Laufs, J ., and Starlinger, P. (1987) Transcription of transposable element Activator (AC) of Zea mays L. EMBO J . 6, 1555-1563.

Linsmaier, E. M. and Skoog, F. (1965) Organic growth factor requirement of tobacco tissue cultures. Physiol. Plant 18, 100127.

Long, D., Martin, M., Sundberg, E., Swinburne, J ., Puangsomlee, P., and Coupland, G. (1993) The transposable element system Ac/Ds as a mutagen in Arabidopsis: identification of albino mutation induced by Ds insertion. Proc. Natl. Acad. Sci. USA 90, 10370-10374.

Machida, C., Onouchi, H., and Machida, Y. (1993) Analysis of plant gene using T-DNA transfer from Agrobacterium. Nippon Nogeikagaku Kaishi 67, 711-715.

Machida, C., Onouchi, H., Koizumi, J ., Hamada, S., Semiarti, E., Torikai, S. and Machida Y. (1997) Characterization of the transposition pattern of the Ac transposable element in Arabidopsis thaliana using endonuclease I-Scel. Proc. Natl. Acad. Sci. USA 94, 8675-8680.

Machida, C., Onouchi, H., Endang, S., I shikawa, T., and Machida, Y. (2000) Use of the R-RS site-specific recombination system in plants. In Gelvin, S.B. (ed.) Plant Molecular Biology Manual. Kluwer Academic Publishers (Netherlands), N2 123.

Matsuzaki, H., Araki, H., and Oshima, Y. (1988) Gene conversion associated with site-specific recombination in yeast plasmid pSR. Mol. Cell. Biol. 8, 955-962.

Medberry, S. L., Dale, E., Qin, M., and Ow. D. W. (1995) Intrachromosomal rearrangements generated by Cre-lox site-specific recombination. Nucleic Acids Res. 23, 485-490.

Moreno, M., Chen, J ., Greenblatt, I., and Dellaporta, S. L. (1992) Reconstitutional mutagenesis of the maize $P$ gene by shortrange Ac transpositions. Genetics 131, 939-956.

Murray, M. G. and Thompson, W. F. (1980) Rapid isolation of high molecular weight plant DNA. Nucleic Acids Res. 8, 43214325.

Nagata, T., Okada, K., Takebe, I., and Matsui, C. (1981) Delivery of tobacco mosaic virus RNA into plant protoplasts mediated by reverse phase evaporation vesicles (liposomes). Mol. Gen. Genet. 184, 161-165.

Nakagawa, Y., Machida, C., Machida, Y., and Toriyama, K. (2000a) Frequency and pattern of transposition of the maize transposable element Ds in transgenic rice plants. Plant Cell Physiol. 41, 733-42.

Nakagawa, Y., Machida, C., Machida, Y., and Toriyama, K. (2000b) A system to induce deletion of genomic sequences using R/RS site-specific recombination and the Actransposon in transgenic rice plants. Theor. Appl. Genet. in press.

Niwa, Y., Muranaka, T., Baba, A., and Machida, Y. (1994) Organspecific and auxin-inducible expression of two tobacco par Arelated genes in transgenic plants. DNA Res. 1, 213-221.

Onouchi, H., Yokoi, K., Machida, C., Matsuzaki, H. Oshima, Y., Matsuoka, K., Nakamura, K., and Machida, Y. (1991) Operation of efficient site-specific recombination system of Zygosaccharomyces rouxii in tobacco cells. Nucleic Acids Res. 19, 6373-6378.

Onouchi, H., Nishihama, R., Kudo, M., Machida, Y., and Machida, C. (1995) Visualization of site-specific recombination catalyzed by a recombinase from Zygosaccharomyces rouxii in Arabidopsis thaliana. Mol. Gen. Genet. 427, 653-660.

Osborne, B. I., Corr, C.A., Prince, J .P. Hehl, R., Tanksley, S.D., McCormick, S., and Baker, B. (1991) Ac transposition from a T-DNA can generate linked and unlinked clusters of insertions in the tomato genome. Genetics 129, 833-844.

Osborne, B. I., Wirtz, U., and Baker, B. (1995) A system for insertional mutagenesis and chromosomal rearrangement using the Ds transposon and Cre-lox. Plant J . 7, 687-701.

Seki, M., Ito, T., Shibata, D., and Shinozaki, K. (1999) Regional insertional mutagenesis of specific genes on the CIC5F 11/ $\mathrm{CIC} 2 \mathrm{~B} 9$ locus of Arabidopsis thaliana chromosome 5 using the Ac/Ds transposon in combination with the cDNA scanning method. Plant Cell Physiol. 40, 624-639.

Springer, P. S., McCombie, W. R., Sundaresan, V. and Martienssen, R. A. (1995) Gene trap tagging of PROLIFERA, as essential MCM2-3-5-like gene in Arabidopsis. Science 268, 877-880.

Tower, J ., Karpen, G. K., Craig, N., and Spradling, A. C. (1993) Preferential transposition of Drosophila P elements to nearby chromosomal sites. Genetics 133, 347-359.

van Haaren, M. J . and Ow, D. W. (1993) Prospects of applying a combination of DNA transposition and site-specific recombination in plants; a strategy for gene identification and 
cloning. Plant Mol. Biol. 23, 525-533.

van Schaik, N. and Brink, R.A. (1959) Transposition of Modulator, a component of the variegated pericarp in maize. Genetics 44, 725-738.

Velten, J ., Velten, L., Hain, R., and Schell, J . (1984) I solation of a dual plant promoter fragment from the $\mathrm{Ti}$ plasmid of Agrobacterium tumefaciens. EMBO J . 3, 2723-2730.

Walbot, V. (1992) Strategies for mutagenesis and gene cloning using transposon tagging and T-DNA insertional mutagenesis. Annu. Rev. Plant Physiol. Plant Mol. Biol. 43, 4982.

Whitham, S., Dinesh-Kumar, S. P., Choi, D., Hehl, R., Corr, C., and Baker, B. (1994) The product of the tobacco mosaic virus resistance gene $\mathrm{N}$ : similarity to Toll and the interleukin-1 receptor. Cell 78, 1-20. 